\title{
ОРГАНІЗАЦІЯ АЕРОМЕДИЧНОЇ ЕВАКУАЦІЇ ПАЦІЄНТІВ ВЕРТОЛЬОТАМИ В УМОВАХ ВІЙСЬКОВИХ ДІЙ НА СХОДІ УКРАЇНИ
}

\author{
В. Ю. Бабій \\ Військово-медичний клінічний центр Центрального регіону (м. Вінниця)
}

Вступ. Аеромедична евакуація є одним з ключових методів евакуації, який забезпечує мобільність та якісне надання медичної допомоги при транспортуванні. Водночас, цей метод евакуації потребує постійного вдосконалення, відповідно до кількісного та якісного складу поранених, вивчення оптимальних та економічно обгрунтованих маршрутів евакуації, оперативної зміни кількості та структури поранень відповідно до зміни військово - політичної обстановки та способів проведення військових дій.

Мета дослідження: вивчення кількісних та якісних показників роботи аеромедичних бригад інтенсивної терапї̈, які проводили евакуацію пацієнтів із зони АТО/ООС за 2015 -2018 роки.

Матеріали та методи. Проведено спостереження та ретроспективний аналіз організації транспортування пацієнтів за період з січня 2015 р. по липень 2018 р. Досліджено карти транспортування пацієнтів високої залежності від надання медичної допомоги за період з березня 2018 року по квітень 2019 року. Загальна кількість транспортованих вертольотами пацієнтів складає 5820. Середній вік пацієнтів з високою залежністю від медичного супроводу склав 30,6士8 років. В кожного із 82 пацієнта був визначений провідний синдром відповідно до причини його транспортування.

Результати. В Україні аеромедична евакуація досягла значних успіхів завдяки взаємодії різних структур та постійною копіткою роботою над удосконаленням техніки їі проведення. Слід відмітити, що кількість поранених залежить від воєнно - політичної обстановки, і відзначається тенденція до зменшення загальної кількості транспортованих хворих у 2015 - 2018 рр. Проте за 2018 - 2019 роки збільшилась питома вага хворих із високою залежністю від медичного супроводу, що може свідчити про зміни в підходах до лікування та відбору пацієнтів для аеромедичної евакуації. Серед транспортованих пацієнтів найбільше було пацієнтів із мінно-вибуховою травмою 45\%, із вогнепальними пораненнями було 28\%, у 10\% транспортованихбули гострі серцево-судинні захворювання, такі як гострий інфаркт міокарда, гострий коронарний синдром або гостре порушення мозкового кровообігу. Також у 10\% пацієнтів були небойові травми, у 5\% були інфекційні захворювання тощо. Під час транспортування 83\% пацієнтам високої категорії залежності від медичного супроводу проводилась штучна вентиляція легень, 68,3\% пацієнтам проводилась медикаментозна седація з метою адаптації до ШВЛ, яка проводилась за раунок пропофолу 87,5\%, натрію оксибутирату 8,9\%, кетаміну 1,8\%, та натрію тіопенталу 3,6\%. У $12.2 \%$ хворих була нестабільна гемодинаміка.

Висновки. Вирішальну роль у раціональному використанні сил та засобів аеромедичної евакуації, відіграють організаційні процеси, ретельний підхід до відбору пацієнтів, правильне формування $i$ оснащення бригад аеромедичної евакуації, а також планування маршрутів евакуації із врахуванням тактичної бойової обстановки та фактичних спроможностей медичних закладів з надання необхідного пацієнту рівня медичної допомоги. В структурі діагнозів серед транспортованих пацієнтів з високою залежністю від медичного супроводу переважають пацієнти із мінно - вибуховою травмою - 45\% та вогнепальними пораненнями - 28\%. Переважна більшість пацієнтів (82,9\%) зазначеної категорії вимагає проведення штучної вентиляції легень, медикаментозної аналгоседації - 68,3\%, а 12,2\% пацієнтам необхідна вазопресорна підтримка гемодинаміки. Вивчення фактичних результатів проведення аеромедичної евакуації, їх аналіз та удосконалення на основі попереднього досвіду дозволить покращити ефективність використання сил та засобів аеромедичної евакуації.

Ключові слова: аеромедична евакуація, маршрути аеромедичної евакуації, структура поранень, кількість транспортованих пацієнтів.

Вступ. Вирішальну роль в процесі лікування поранених відіграє аеромедична евакуація пацієнтів, яка є невід'ємною частиною заходів медичної евакуації поранених та хворих пацієнтів із зони бойових конфліктів, особливо для пацієнтів в критичних станах, оскільки очевидним є те, що такі пацієнти потребують найвищого рівня надання медичної допомоги, а час їхнього транспортування має бути мінімальним. У випадку транспортування пацієнта від місця поранення, єдиним можливим повітряним транспортом $є$ вертольот, оскільки він може сісти практично на будь-якій рівній площадці, в деяких випадках прямо біля лікарні, завантаження й вивантаження з нього може 
здійснюватися дуже швидко, навіть при працюючих двигунах [6, 7]. Швидкість сучасних медичних гвинтокрилів 200 - 300 км/год. Не дивлячись на те, що у кабіні великий рівень шуму, а високий рівень вібрації може перешкоджати роботі деякого медичного обладнання, викликати дискомфорт у медичної бригади i виснаження хворого, вертольот залишається єдиним засобом швидкої доставки пораненого до спеціалізованого рівня надання медичної допомоги, якого потребують пацієнти в критичних станах.

Першою державою, яка застосувала вертольоти у військових цілях $є$ США. В часи Другої світової війни, з квітня 1944 року вертольоти VS-316 (армійське позначення R4B) почали використовуватися в бойових діях на території Бірми і на сході Індії в цілях постачання висаджених десантників і евакуації поранених [3-5].

Активне використання гелікоптерів для евакуації поранених розпочалося під час Корейської війни. Це було зумовлено потребою швидко вивозити поранених з місця бойових дій в умовах пересіченої місцевості. Гелікоптерами вдалось успішно перевезти майже 22000 пацієнтів, i саме евакуація повітрям сприяла зниженню рівня смертності серед поранених. Бойовий досвід американців у Кореї, британців у Малайї і французів в Індокитаї довів, що гвинтокрили $\epsilon$ неоціненним транспортним засобом, який суттєво вплинув на зниження рівня смертності пацієнтів. Під час війни у В’єтнамі гелікоптери міцно утвердились як найважливіший компонент системи медичної аероевакуації на сучасному полі бою [1-3]. Гвинтокрили, які використовують для аеромедичної евакуації, $\epsilon$ на сьогодні основним транспортним засобом для вивезення поранених із поля бою та найближчих прифронтових госпіталів чи стабілізаційних пунктів. Вважається, що завдяки застосуванню гелікоптерів поліпшуються збройна підтримка медичної служби і догляд пацієнтів, а також підвищується рівень виживання військових.

Таким чином, аеромедична евакуація $\epsilon$ одним 3 ключових методів евакуації, який забезпечує мобільність та якісне надання медичної допомоги при транспортуванні. Водночас, цей метод евакуації потребує постійного вдосконалення, відповідно до кількісного та якісного складу поранених, вивчення оптимальних та економічно обгрунтованих маршрутів евакуації, оперативної зміни кількості та структури поранень відповідно до зміни військово політичної обстановки та способів проведення військових дій.

Матеріали та методи дослідження. Проведено спостереження та ретроспективний аналіз організації транспортування пацієнтів за період з січня 2015 р. по липень 2018 р. Досліджено карти транспортування пацієнтів високої залежності від надання медичної допомоги за період з березня 2018 року по квітень 2019 року. Загальна кількість транспортованих вертольотами пацієнтів складає 5820. Середній вік пацієнтів з високою залежністю від медичного супроводу склав $30,6 \pm 8$ років. В кожного із 82 пацієнта був визначений провідний синдром відповідно до причини його транспортування.

Результати та їx обговорення. Основним гвинтокрилом, який використовується для евакуації поранених в Україні є Мi - 8 (рис. 1), який, в залежності від тактичного призначення та конфігурації, може транспортувати до 12 пацієнтів на ношах. Транспортні гелікоптери за короткий час доукомплектовуються санітарними стійками та ременями для встановлення нош, а також портативною медичною апаратурою на акумуляторах та балонами з медичним киснем. Для перевезення поранених сидячи застосовуються відкидні сидіння ці сидіння згруповані по три або два. При відкиданні 6-и сдінь (зпереду), або 5-и сидінь (позаду) на їх місці встановлюються стійки санітарні та натягуються ремені для встановлення в них 3 нош. На таких стійках 3 ношами, при завантаженні зверху вниз, можна розмістити трьох хворих лежачи. При наявності важкохворого 3 високою залежністю від медичного супроводу (необхідність проведення ШВЛ та інтенсивної терапії в польоті) кількість хворих, що транспортуються лежачи, зменшується до одного, оскільки нижні ноші використовуються для медичного обладнання та медикаментів, а ноші, які знаходяться вгорі не використовуються, щоб полегшити доступ до пацієнта, який в цьому випадку розміщується в середньому ярусі, для полегшеного догляду, підключення 
спеціалізованої апаратури та візуального спостереження за ним (рис. 2).

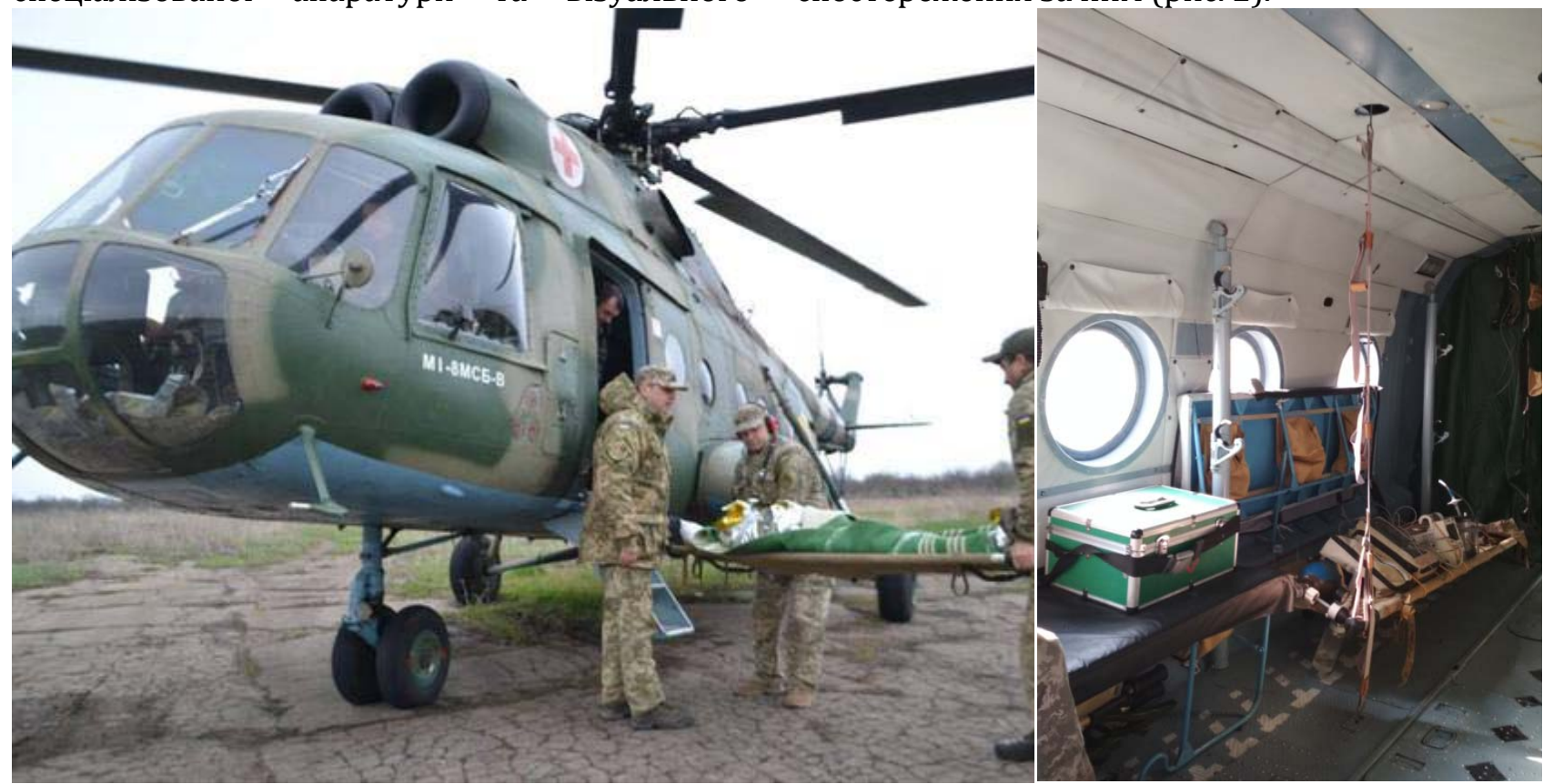

Рисунок 1. Гвинтокрил Мі-8 вигляд зовні (зліва) та готовий для транспортування важкопораненого лежачи (праворуч).
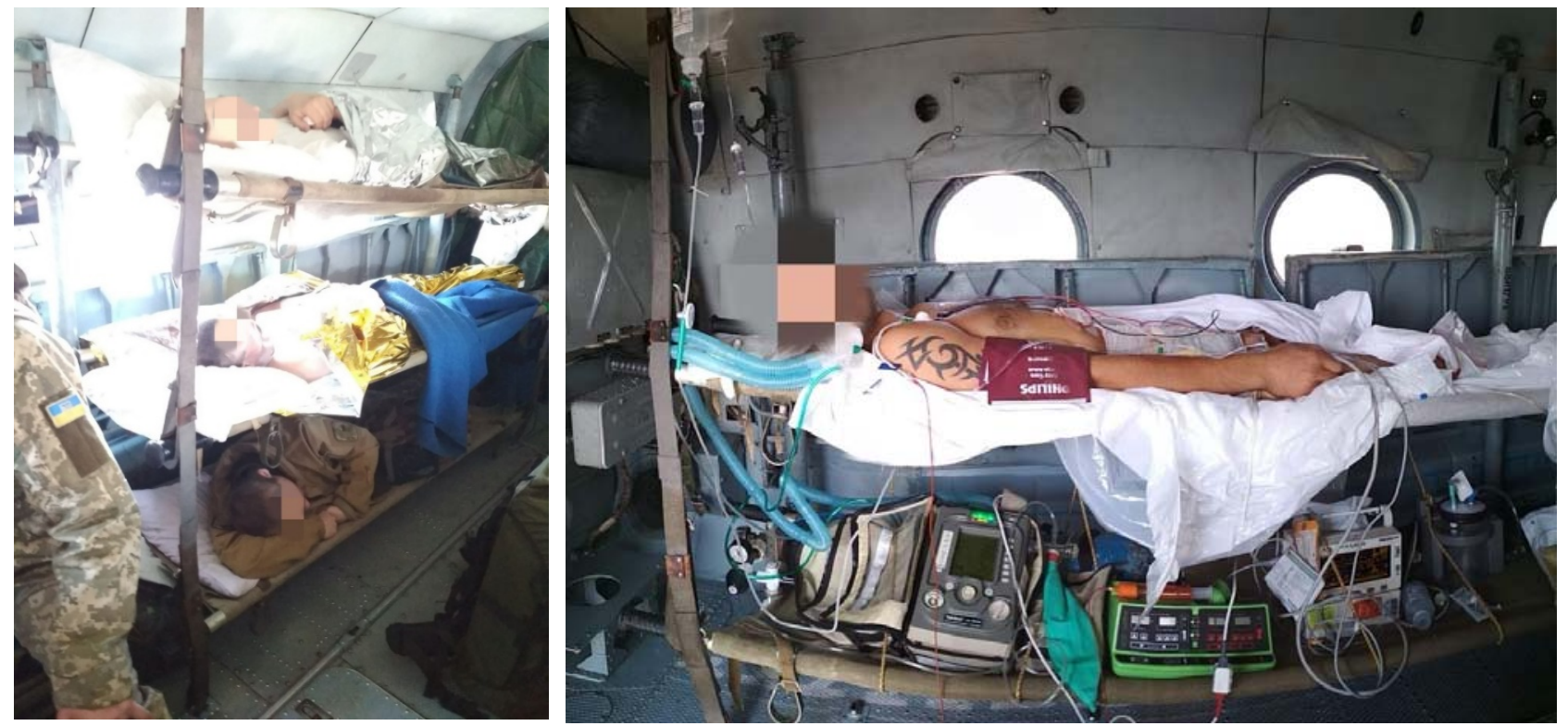

Рисунок 2. Гвинтокрил Мі-8. Способи транспортування поранених лежачи. Варіант розміщення трьох лежачих пацієнтів (зліва) та одного важкохворого із високою залежністю від медичного супроводу (праворуч).

3 початку війни на сході України для евакуації поранених із поля бою досить часто використовувались вертольоти, проте згодом, після прийняття «Мінських домовленостей» та визначенням меж «без польотної зони» для військової авіації, евакуація вертольотами почала здійснюватися 3 етапів медичної евакуації (стабілізаційних пунктів та військових мобільних шпиталів).

Нині, в умовах гібридної агресії на сході України, аеромедична евакуація поранених здійснюється, в основному, трьома медичними групами. Це аеромедичні бригади інтенсивної терапії (АМБІТ) 65 Військового мобільного госпіталя (ВМГ) (далі - бригада м. Краматорськ) та 59 ВМГ (далі - бригада м. Сєвєродонецьк), а також бригада відділення медичного забезпечення аеромедичної евакуації Військово - медичного центру Східного регіону (далі - бригада м. Дніпро). Вони здійснюють евакуацію із військових мобільних госпіталів, далі ВМГ (59) ВМГ 
м. Сєвєродонецьк, 65 ВМГ м Часів Яр, 66 ВМГ м. Покровськ, 61 ВМГ м. Маріуполь).

У кожного мобільного госпіталя є від 1 до 5 стабілізаційних пунктів (лікарсько сестринських бригад), які розташовані на базі діючих цивільних лікарень населених пунктів в зоні ООС, максимально наближені до лінії зіткнення та надають медичну допомогу в перші хвилини (години) після поранення. Біля деяких $з$ цих передових груп визначені злітно - посадкові майданчики де можна завантажити поранених у вертольот, та здійснити евакуацію, оминаючи етап Військового мобільного госпіталя. Загалом таких майданчиків дев'ять.

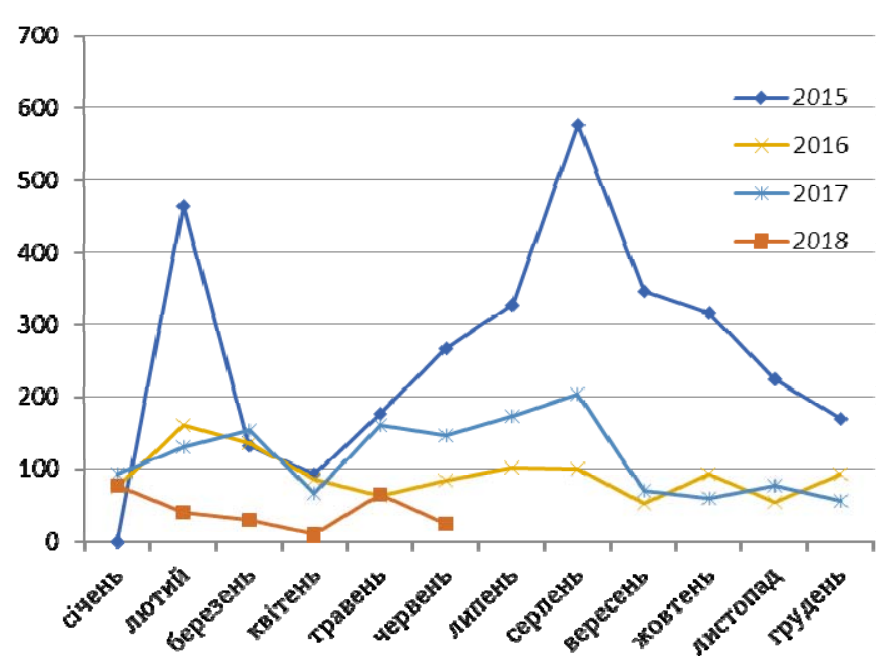

Рисунок 3. Загальна кількість пацієнтів, транспортованих вертольотами за період 2015 - 2018 рр. дослідження по місяцях і роках.

Кожна аеромедична місія 3 транспортування пацієнтів вертольотом в умовах безпосередньої близькості до лінії зіткнення планується під конкретних пацієнтів, швидкість надання допомоги яким відіграє вирішальну роль. В основному це важкі хворі, зі високою залежністю від надання медичної допомоги, яким необхідне проведення складного оперативного втручання або виконання додаткового обстеження, які не доступні в умовах стабілізаційного пункту, чи військового мобільного госпіталя. Частіше всього такі пацієнти транспортуються на штучній вентиляції, пресорній підтримці гемодинаміки або під пильним моніторингом життєвоважливих функцій. Такі пацієнти вимагають високого рівня організації місії та злагодженої роботи медичного персоналу і
Загальна кількість транспортованих вертольотами пацієнтів складає 5820. В тому числі за 2015 рік було транспортовано 3091 пацієнт, в 2016 році 1096 пацієнтів, в 2017 році 1390, а за шість місяців 2018 року 243 поранених та хворих (рис. 1). Кількість транспортованих пацієнтів вказаними бригадами за період з січня 2015 р. по липень 2018 р. складає відповідно: для бригади м. Дніпро 3320 або 57\%, для бригади м. Краматорськ 1536 або 26\% та бригада м. Сєвєродонецьк транспортувала 964 пацієнта, або $17 \%$ (рис. 4.).

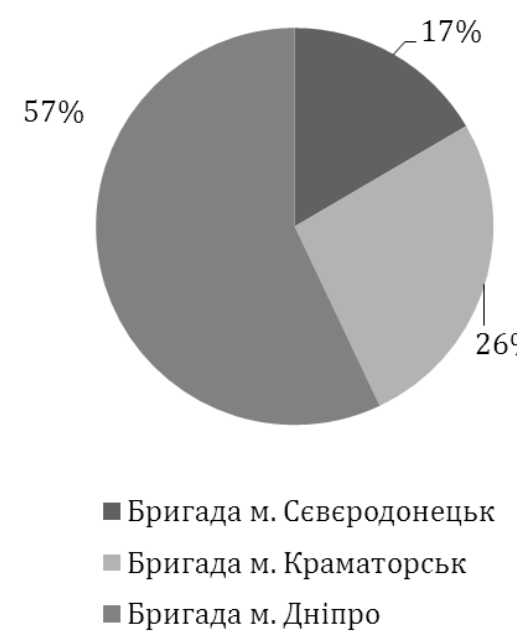

Рисунок 4. Розподіл транспортованих пацієнтів між бригадами, які здійснювали транспортування.

авіаційних підрозділів, оскільки найменша помилка чи зволікання може призвести до тяжких, а іноді навіть фатальних наслідків.

Нами було проаналізовано кількість пацієнтів із високою залежністю від медичного супроводу (які транспортувались на штучній вентиляції, вазопресорній підтримці гемодинаміки або під пильним моніторингом життєвоважливих функцій, рис. 5). Розглянувши показники роботи трьох бригад, видно, що бригади в мм. Сєвєродонецьк та Краматорськ мали найбільше навантаження у порівнянні з м. Дніпро.

Результати дослідження роботи аеромедичної бригади інтенсивної терапії, м. Краматорськ. Особовий склад бригади складається 3 лікаря анестезіолога та медичної сестри - анестезиста, які працюють на ротаційній основі, їх зміна відбувається 
один раз на квартал. Час спостереження: 384

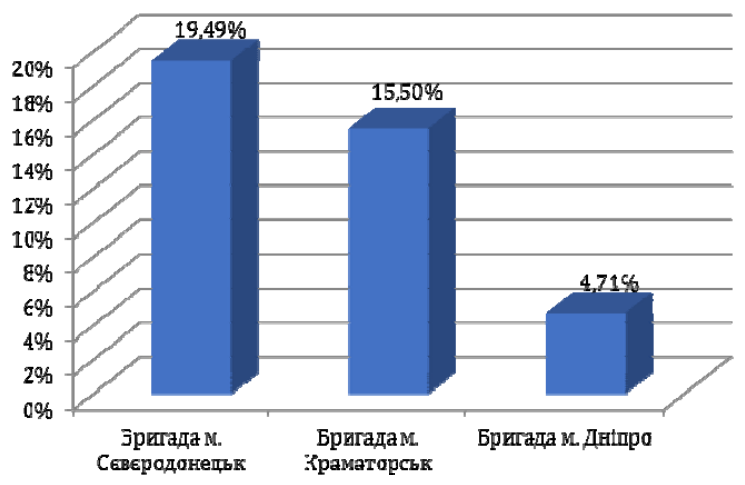

Рисунок 5. Відносна кількість хворих, які транспортувались на штучній вентиляції легень, пресорній підтримці гемодинаміки або під пильним моніторингом життєвоважливих функцій 2015 -2018 pp.

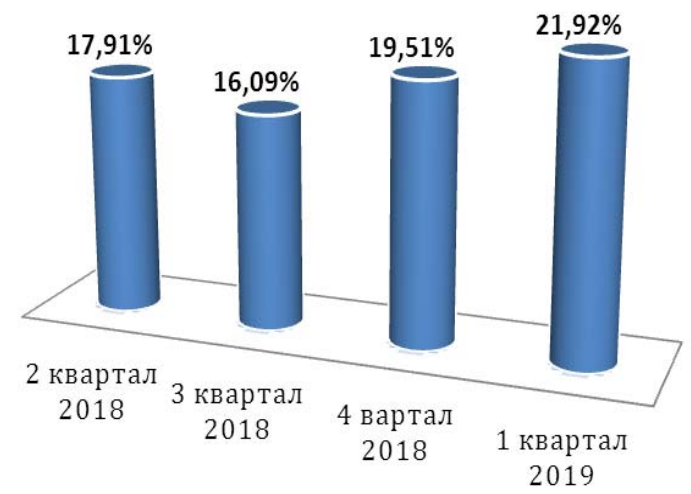

Рисунок 7. Динаміка зміни кількості пацієнтів із високою залежністю від медичного супроводу.

Слід відмітити, що кількість поранених залежить від воєнно - політичної обстановки, і відзначається тенденція до зменшення загальної кількості транспортованих хворих у 2015 - 2018 рр. (рис. 3). Проте за 2018 - 2019 роки збільшилась питома вага хворих із високою залежністю від медичного супроводу (рис. 7), що може свідчити про зміни в підходах до лікування та відбору пацієнтів для аеромедичної евакуації.

Необхідність в плануванні аеромедичної місії виникає, в основному, при появі пацієнтів у важкому та вкрай важкому стані (із високою залежністю від надання медичної допомоги), яким необхідний перевід на вищий етап лікування для принципової зміни дні.

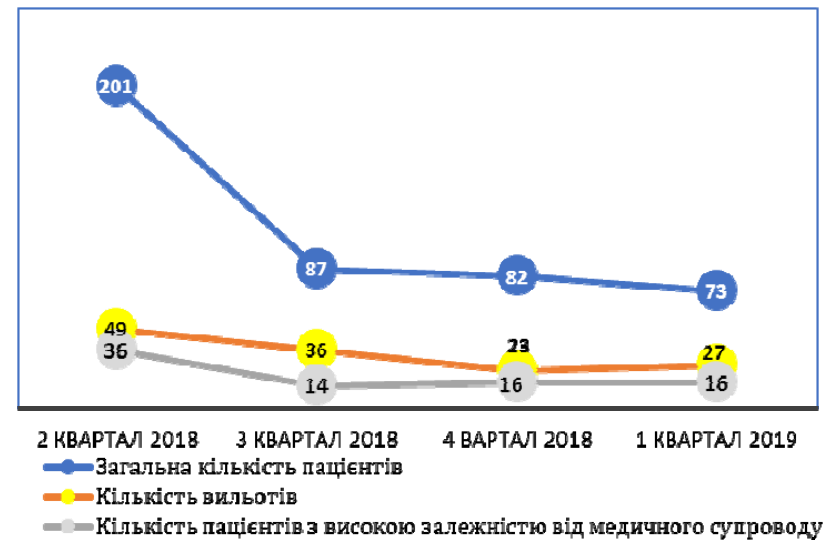

Рисунок 6. Динаміка кількісних показників роботи аеромедичних бригад. Загальна кількість вильотів: 135. Загальна кількість транспортованих пацієнтів: 443, із них пацієнтів із високою залежністю від медичного супроводу: 82.

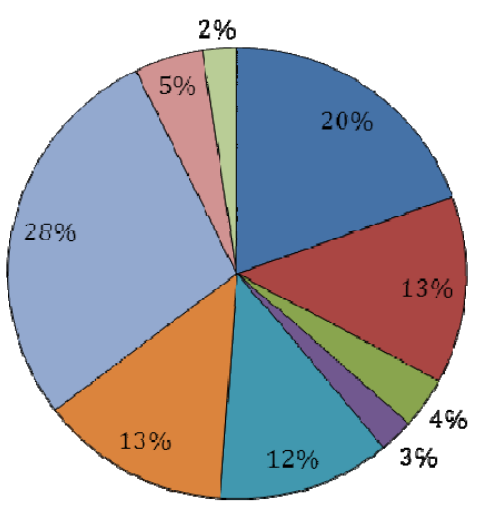

$$
\begin{aligned}
& \text { 口Часів Яр (65 ВМГ) } \\
& \text { 口Бахмут (65 ВМГ) } \\
& \text { 口Краматорск (65 В.МГ) } \\
& \square \text { Торецьк (65 ВМГ) } \\
& \text { 口Пекровськ (66 ВМГ) } \\
& \text { 口Авдіївка (66 ВM:) } \\
& \text { 口Маріуполь (61 ВМГ) } \\
& \text { 口Волноваха (61 ВМГ) } \\
& \square \text { Северодонецьк (59 } \\
& \mathrm{BM} \text { ) }
\end{aligned}
$$

Рисунок 8. Структура вильотів по населених пунктах звідки транспортувались поранені високого ступеню залежності від медичного супроводу аеромедичною бригадою інтенсивної терапії м. Краматорськ, що підпорядкована 65 ВМГ.

якості надання медичної допомоги чи виконання хірургічного втручання, яке не можливо провести на даному рівні, а також для яких вирішальну роль для медичних та соціальних наслідків лікування відіграє час, за який вони потраплять на етап спеціалізованої та високоспеціалізованої медичної допомоги.

Тому, проаналізувавши маршрути транспортування пацієнтів 3 високим ступенем залежності від надання медичної допомоги, можливо визначити осередки найбільших санітарних втрат та прогнозувати потреби в медичному забезпеченні військ на 
певному напрямку. Безумовно необхідно зважати на географічне розташування бригади показники якої аналізуються та їі підпорядкованість за субординацією, оскільки застосування аеромедичних бригад $\epsilon$ економічно обгрунтованим у суміжних районах, разом 3 тим певні тенденції, які відображають напруженість роботи медичної служби на певних напрямках є очевидними.

На кожного пацієнта із категорії високої залежності від медичного супроводу під час транспортування велась карта транспортування (аналог карти анестезії), в якій документувались провідний синдром у пацієнта, показники моніторування життєвоважливих функцій, дози введених медикаментів та протоколювався стан пацієнта на основних етапах транспортування (при завантаженні у вертольот, під час аеромедичного транспортування та при передачі бригаді на аеродромі призначення). Аналіз карт транспортування 82-х пацієнтів показує (рис. 8), що найбільша кількість транспортованих пацієнтів для даної аеромедичної бригади були із зони відповідальності 65 Військового мобільного госпіталя - 40\% (м. Часів Яр - 20\%, м. Бахмут $13 \%$, м. Краматорськ 4\% та м. Торецьк - 3\%). Із зони відповідальності 61 ВМГ- 32\% (м. Маріуполь 28\% та стабілізаційний пункт м. Волноваха - 4\%). Із зони відповідальності 66 ВМГ - 25\% ( Авдіївка 13\% та м. Покровськ 12\%). Із зони відповідальності 59 ВМГ було здійснено $2 \%$ евакуаційю. Це можна пояснити тим, що практично всі евакуації 3 цього напрямку здійснюються силами аеромедичних бригад м. Сєверодонецьк. Транспортування пацієнтів відбувалось за наступними напрямками: Харків-84\% пацієнтів, Дніпро-15\%, і безпосередньо в аеропорт Бориспіль 1\% (рис. 9). Середній вік пацієнтів 3 високою залежністю від медичного супроводу склав $30,6 \pm 8$ років.

В кожного із 82 пацієнта був визначений провідний синдром відповідно до причини його транспортування. Таким чином серед транспортованих пацієнтів найбільше було пацієнтів із мінно - вибуховою травмою 37 пацієнтів (45\%), із вогнепальними пораненнями було 23 пацієнта (28\%), у восьми транспортованих (10\%) були гострі серцево - судинні захворювання, такі як гострий інфаркт міокарда, гострий коронарний синдром або гостре порушення мозкового кровообігу. Також у восьми пацієнтів (10\%) були небойові травми, у чотирьох (5\%) були інфекційні захворювання такі, як пневмонія, перикардит та ботулізм, а у двох хворих (2\%) були гострі отруєння невідомою речовиною (рис. 10).

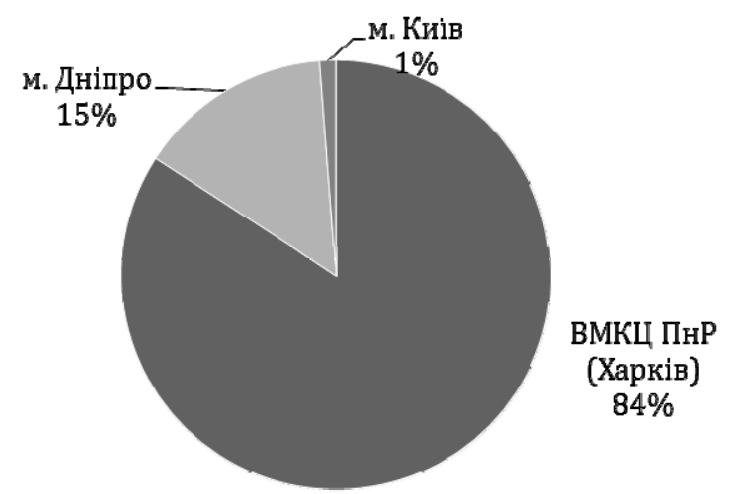

Рисунок 9. Структура вильотів по госпіталям куди транспортувались поранені високого ступеня залежності від медичного супроводу аеромедичною бригадою інтенсивної терапії м. Краматорськ, що підпорядкована 65 ВМГ.

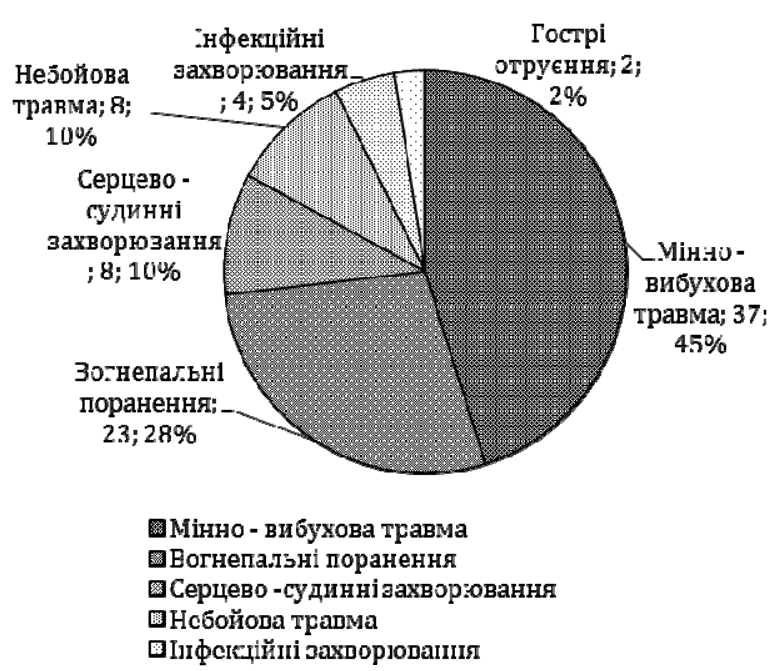

Рисунок 10. Структура пацієнтів, які транспортувались із високою залежністю від медичного супроводу за 384 дні 2018 2019 pр. (абсолютні та відносні числа).

Як згадувалось вище, проводився аналіз пацієнтів високої категорії залежності від медичного супроводу, тобто яким проводилась штучна вентиляція легень та/або пресорна підтримка гемодинаміки. Середній час транспортування кожного такого пацієнта склав $72,8 \pm 20,1$ хвилин.

Під час транспортування 68 (82,9\%) пацієнтів високої категорії залежності від 
медичного супроводу проводилась штучна вентиляція легень, 56 (68,3\%) пацієнтам проводилась медикаментозна седація з метою адаптації до ШВЛ, яка проводилась за рахунок пропофолу 87,5\%, натрію оксибутирату 8,9\%, кетаміну $1,8 \%$, та натрію тіопенталу $3,6 \%$. У $10 \quad(12,2 \%)$ хворих була нестабільна гемодинаміка, у звязку із чим їм проводилась інфузія вазопресорів (норадреналін - 70\% та дофамін - 30 \% з усіх паціїнтів нестабільною гемодинамікою). Таким чином, від початку

\section{Висновки.}

1. В структурі діагнозів серед транспортованих пацієнтів 3 високою залежністю від медичного супроводу переважають пацієнти із мінно - вибуховою травмою - $45 \%$ та вогнепальними пораненнями - 28\%. Переважна більшість пацієнтів $(82,9 \%)$ зазначеної категорії вимагає проведення штучної вентиляції легень, медикаментозної аналгоседації $68,3 \%$, а $12,2 \%$ пацієнтам необхідна вазопресорна підтримка гемодинаміки.

2. Транспортування пацієнтів за досвідом АТО/ООС відбувається переважно до Військово - медичного клінічного центру Північного регіону м. Харків, оскільки якомога швидша доставка пацієнта до медичного закладу, який може забезпечити необхідний рівень надання медичної допомоги, має вирішальний вплив на успіх лікування та прогноз важких та вкрай важких пацієнтів.

3. Для раціонального використання евакуаційних місць в повітряних суднах, після визначення маршруту та часу евакуації критично хворих пацієнтів, проводиться відбір пацієнтів, у яких швидкість

\section{References}

1. North Atlantic Treaty Organisation. STANAG 3204 AMD (edition6): aeromedical evacuation. Brussels, Belgium: NATO; 15 July 1999.

2. Fear, N.T., Jones, M., Murphy, D., Hull, L, Iversen $\mathrm{AC}$, et al. (2010). What are the consequences of deployment to Iraq and Afghanistan on the mental health of the UK armed forces? A cohort study. Lancet; 375:1783-97.

3. Sanders, J.W., Putnam, S.D., Frankart, C., Frenck, R.W., Monteville, M.R., et al. (2005). Impact of illness and non-combat injury during Operations Iraqi Freedom and Enduring Freedom (Afghanistan). Am J Trop Med Hyg; 73:713-9. військових дій на Сході України знижується загальна кількість поранених, але збільшується питома вага пацієнтів категорії високої залежності від медичного супроводу. На основі аналізу показників однієї з трьох бригад. які здійснюють аеромедичну евакуацію пацієнтів із зони АТО/OOC підтверджено тенденцію до поквартального зниження загальної кількості евакуйованих пацієнтів та до зростання питомої ваги важкопоранених. транспортування можливо i не відіграє вирішальної ролі, але $\epsilon$ доцільною, для якомога швидшого одужання. Такі пацієнти транспортуються сидячи, чи лежачи та їх кількість залежить від евакоємності вертольота для максимально корисного використання евакомісць.

4. Вирішальну роль у раціональному використанні сил та засобів аеромедичної евакуації, відіграють організаційні процеси, ретельний підхід до відбору пацієнтів, правильне формування і оснащення бригад аеромедичної евакуації, а також планування маршрутів евакуації із врахуванням тактичної бойової обстановки та фактичних спроможностей медичних закладів з надання необхідного пацієнту рівня медичної допомоги.

5. Вивчення фактичних результатів проведення аеромедичної евакуації, їх аналіз та удосконалення на основі попереднього досвіду дозволить покращити ефективність використання сил та засобів аеромедичної евакуації.

4. Venticinque, S.G., Grathwohl, K.W. (2008). Critical care in the austere environment: providing exceptional care in unusual places. Crit Care Med; 36(7, Suppl.):S28492.

5. Warren, J., Fromm, R.E. Jr., Orr, R. A. et al. (2004).Guidelines for the inter- and intrahospital transport of critically ill patients. Crit. Care Med. Vol. 32, No 1. P. 256-262.

6. Медична евакуація повітрям [Електронний pecypc]. Режим доступу http://www.aumf.net/emergencywarsurgery/ukr_chapt ers/EMS_Chapter04.pdf

7. Mabry, R., Apodaca, A., Penrod, J., Orman, J. A., Gerhardt, R.T., Dorlac, W.C. (2012). Impact of critical care 
trained flight paramedics on casualty survival during TraumaAcute Care Surg.;3(2 Suppl 1):S32 helicopter evacuation in the current war in Afghanistan. J

\title{
ОРГАНИЗАЦИЯ АЭРОМЕДИЦИНСКОЙ ЭВАКУАЦИИ ПАЦИЕНТОВ ВЕРТОЛЕТОВ В УСЛОВИЯХ ВОЕННЫХ ДЕЙСТВИЙ НА ВОСТОКЕ УКРАИНЫ
}

\section{В. Ю. Бабий}

Военно-медицинский клинический центр Центрального региона (2. Винница)

Введение. Аэромедицинская эвакуация является одним из ключевых методов эвакуации, который обеспечивает мобильность и качественное оказание медицинской помощи при транспортировке. В то же время, этот метод эвакуации требует постоянного совершенствования, в соответствии $c$ количественного и качественного состава раненых, изучение оптимальных и экономически обоснованных маршрутов эвакуации, оперативного изменения количества и структуры ранений в соответствии $c$ изменением военно - политической обстановки и способов проведения военных действий.

Цель исследования: изучение количественных и качественных показателей работы аэромедицинских бригад интенсивной терапии, проводили эвакуацию пациентов из зоны АТО / ООС за 2015 -2018 годы.

Материалы и методы. Проведены наблюдения и ретроспективный анализ организации транспортировки пациентов за период с января 2015 по июль 2018 годы. Исследованы карты транспортировки пациентов высокой зависимостью от оказания медицинской помощи за период $c$ марта 2018 по апрель 2019 годы. Общее количество транспортируемых вертолетами пациентов составляет 5820. Средний возраст пациентов с высокой зависимостью от медицинского сопровождения составил 30,6 8 лет. У каждого из 82 пациента был определен ведущий синдром согласно причины его транспортировки.

Результаты. В Украине аэромедицинская эвакуация достигла значительных успехов благодаря взаимодействию различных структур и постоянной кропотливой работой над совершенствованием техники ее проведения. Следует отметить, что количество раненых зависит от военно - политической обстановки, и отмечается тенденция к уменьшению общего количества транспортируемых больных за 2015 - 2018 г2. Но за 2018 - 2019 годы увеличился удельный вес больных с высокой зависимостью от медицинского сопровождения, что может свидетельствовать о изменения в подходах к лечению и отбора пациентов для аэромедицинской эвакуации. Среди транспортируемых пациентов всего было пациентов с минно-взрывной травмой 45\%, с огнестрельными ранениями было 28\%, у $10 \%$ транспортованихбулы острые сердечно-сосудистые заболевания, такие как острый инфаркт миокарда, острый коронарный синдром или острое нарушение мозгового кровообращения. Также у $10 \%$ пациентов были небоевые травмы, у 5\% были инфекционные заболевания и тому подобное. Во время транспортировки 83\% пациентам высокой категории зависимости от медицинского сопровождения проводилась искусственная вентиляция легких, 68,3\% пациентам проводилась медикаментозная седация с целью адаптации к ИВЛ, которая проводилась по раунок пропофола 87,5\%, натрия оксибутирата 8,9\%, кетамина 1 , 8\%, и натрия тиопентала 3,6\%. В 12.2\% больных была нестабильная гемодинамика.

Выводы. Решаюшую роль в рациональном использовании сил и средств аэромедицинской эвакуации играют организационные процессы, тщательный подход к отбору пациентов, правильное формирование и оснащение бригад аэромедицинской эвакуации, а также планирование маршрутов эвакуации с учетом тактической боевой обстановки и фактических возможностей медицинских учреждений по оказанию необходимого пациенту уровня медицинской помощи. В структуре диагнозов среди транспортируемых пациентов с высокой зависимостью от медицинского сопровождения преобладают пациенты с минно - взрывной травмой - 45\% и огнестрельными ранениями - $28 \%$. Подавляющее большинство пациентов (82,9\%) указанной категории требует проведения искусственной вентиляции легких, медикаментозной аналгоседации - 68,3\%, а 12,2\% пациентам необходима вазопрессорная поддержка гемодинамики. Изучение фактических результатов проведения аэромедицинской эвакуации, их анализ и совершенствование на основе предыдущего опыта позволит повысить эффективность использования сил и средств аэромедицинской эвакуации.

Ключевые слова: аэромедицинская эвакуация, маршруты аэромедицинской эвакуации, структура ранений, количество транспортируемых пациентов.

\section{ORGANIZATION OF AEROMEDICAL EVACUATION OF PATIENTS BY HELICOPTERS AT COMBAT CONDITIONS IN EASTERN UKRAINE}

\author{
V. Yu. Babiy
}

Military Medical Clinical Center of the Central Region (Vinnytsia) 
Introduction. Aeromedical evacuation is one of the key methods of evacuation, which ensures mobility and quality medical care during transportation. At the same time, this method of evacuation requires constant improvement, in accordance with the quantitative and qualitative composition of the wounded, study of optimal and economically justified evacuation routes, prompt change of the number and structure of wounds in accordance with changing military - political situation and methods of hostilities.

The purpose: to study the quantitative and qualitative indicators of the aeromedical teams of intensive care, which carried out the evacuation of patients from the ATO / JFO zone for 2015-2018.

Materials and methods. Observations and retrospective analysis of the organization of patient transportation for the period from January 2015 to July 2018 were conducted. Maps of transportation of patients highly dependent on medical care for the period from March 2018 to April 2019 were studied. The total number of patients transported by helicopter is 5820. The average age of patients with high dependence on medical care was $30.6 \pm 8$ years. In each of the 82 patients, the leading syndrome was identified according to the reason for its transportation.

Results. In Ukraine, aeromedical evacuation has achieved significant success due to the interaction of various structures and constant painstaking work to improve the technique of its implementation. It should be noted that the number of wounded depends on the military - political situation, and there is a tendency to reduce the total number of transported patients in 2015 - 2018. However, in 2018 - 2019 the proportion of patients with high dependence on medical care increased, which may indicate changes in approaches to treatment and selection of patients for aeromedical evacuation. Among the transported patients, the majority were patients with mine injuries (45\%), with gunshot wounds 28\%, $10 \%$ of those transported had acute cardiovascular diseases such as acute myocardial infarction, acute coronary syndrome or acute cerebrovascular accident. Also, 10\% of patients had non-combat injuries, 5\% had infectious diseases and so on. During transportation, 83\% of patients in the high category of dependence on medical support underwent artificial lung ventilation, 68.3\% of patients underwent medical sedation to adapt to mechanical ventilation, which was carried out at the rate of propofol $87.5 \%$, sodium oxybutyrate $8.9 \%$, ketamine 1, 8\%, and sodium thiopental 3.6\%. 12.2\% of patients had unstable hemodynamics.

Conclusions. Critical role in the rational use of forces and means of air medical evacuation is played by organizational processes, careful approach to patient selection, proper formation and equipment of air medical evacuation teams, as well as planning of evacuation routes taking into account the tactical combat situation and the actual level of medical care. assistance. The structure of diagnoses among transported patients with high dependence on medical support is dominated by patients with mine injuries - 45\% and gunshot wounds - 28\%. The vast majority of patients (82.9\%) in this category require artificial lung ventilation, medical analgesia - 68.3\%, and $12.2 \%$ of patients need vasopressor hemodynamic support. Studying the actual results of aeromedical evacuation, their analysis and improvement based on previous experience will improve the efficiency of the use of forces and means of aeromedical evacuation.

Key words: aeromedical evacuation, routes of aeromedical evacuation, structure of injuries, number of transported patients.

\section{Відомості про авторів:}

Бабій В. Ю., підполковник медичної служби, ординатор відділення анестезіології і реанімації Військово-медичного клінічного центру Центрального регіону (м. Вінниця).

Сведения об авторах:

Бабий В. Ю., подполковник медицинской службы, ординатор отделения анестезиологии и реанимации Военно-медицинского клинического центра Центрального региона (г. Винница).

\section{Information about authors:}

Babiy V. Yu., LtC MS, resident of the department of anesthesiology and resuscitation of the Military Medical Clinical Center of the Central Region (Vinnytsia).

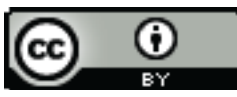

Адреса для листування:

вул. Князів Коріатовичів,

буд. 185, м. Вінниця, 